\title{
Ethanol Consumption Affects Lipoprotein Lipase Gene Expression in C57BL/6 Mice
}

\author{
E. MUDRÁKOVÁ ${ }^{1,2}$, J. KOVÁŔ $\check{R}^{1,2}$ \\ ${ }^{1}$ Institute for Clinical and Experimental Medicine, Laboratory for Atherosclerosis Research and \\ ${ }^{2}$ Center for Cardiovascular Research, Prague, Czech Republic
}

Received March 12, 2007

Accepted June 1, 2007

\begin{abstract}
Summary
The activity of lipoprotein lipase (LPL) is increased after alcohol consumption and can contribute to an increased level of HDL-cholesterol, which is considered to play a key role in the ethanol-mediated protective effect against cardiovascular disease. The increase in HDL-cholesterol concentration can be also due to an ethanol-enhanced synthesis and secretion of apolipoprotein A-I (apo A-I) from hepatocytes. Therefore, the hypothesis that ethanol consumption affects the LPL and apo A-I gene (LPL and APOA1, respectively) expression was tested in male C57BL/6 mice drinking $5 \%$ ethanol or water and fed a standard chow or high-fat (HF) diet for 4 weeks. The LPL expression was determined in the heart, epididymal and dorsolumbal adipose tissues, the APOA1 expression in the liver. Alcohol consumption did not affect lipid and lipoprotein concentrations in the serum. The $L P L$ expression was increased in the heart of mice given ethanol and HF diet compared to mice on chow and ethanol $(p<0.001)$ and was also increased in epididymal fat in mice given ethanol and HF diet compared to mice on water and HF diet $(\mathrm{p}<0.05)$. Neither $L P L$ expression in dorsolumbal fat nor APOA1 expression in the liver were affected by ethanol consumption. Our data suggest that ethanol consumption upregulate $L P L$ expression in a tissue- and diet-dependent manner.
\end{abstract}

\section{Key words}

Apolipoprotein A-I $\bullet$ Lipoprotein lipase $\bullet$ Ethanol consumption $\bullet$ Gene expression $\bullet$ Mouse

It has been repeatedly documented that moderate alcohol consumption protects against cardiovascular disease (Langer et al. 1992, Rimm et al. 1996, Cordova et al. 2005). The substantial part of such a protective effect is due to the effect of ethanol on plasma lipoproteins, especially on the increase in HDL-cholesterol (HDL-C) concentration (Criqui et al. 1987, Suh et al. 1992, Gaziano et al. 1993). Such an increase can be explained by increased lipoprotein lipase (LPL) activity resulting in enhanced transfer of surface components (cholesterol and phospholipids) from triglyceride-rich lipoproteins (TRL) to HDL during the lipolysis of TRL-triglycerides. It has been shown that LPL activity is indeed increased after a period of alcohol consumption in humans (Schneider et al. 1985, Nishiwaki et al. 1994, Kovář and Poledne 2004). However, the exact mechanism of LPL upregulation by ethanol consumption has not been elucidated yet. Another explanation of increased HDL-C can be ethanol-stimulated secretion of apolipoprotein A-I (apo A-I) by hepatocytes (Amarasuriya et al. 1992, 
Dashti et al. 1996). Therefore, we hypothesized that alcohol consumption upregulates LPL and apo A-I at the level of gene expression. To test this hypothesis, we measured the expression of LPL and apo A-I genes (LPL and $A P O A 1$, respectively) in C57BL/6 mice drinking $5 \%$ ethanol and fed either a standard chow or high-fat (HF) diet. It is known that LPL is regulated in a tissue-specific manner. Hence, the $L P L$ expression was determined in the heart and two types of adipose tissue - epididymal and dorsolumbal fat. The expression of APOA1 was measured in the liver.

Two-month-old male C57BL/6 mice $(\mathrm{n}=39)$ weighing $23.9 \pm 2.4 \mathrm{~g}$ were used in the study. The animals were randomly divided into four groups $(n=9-10)$ and housed under a 12:12 h light/dark cycle condition (lights turned on at 6:00 h) with a free access to standard laboratory (ST) chow for 1 week for acclimatization. Thereafter the animals received water and ST diet (group I), $5 \%$ ethanol (EtOH) and ST diet (group II), water and high-fat (HF) diet (chow containing $5 \%$ fat - lard) (group III), and EtOH and HF diet (group IV) for the following 4 weeks. The animals were fed ad libitum and the consumption of diets and liquids as well as weight of the animals were recorded. At the end of the alcohol and diet treatment, the animals were fasted overnight, decapitated and blood was collected for lipid and lipoprotein analysis. Samples of $\sim 30 \mathrm{mg}$ of heart $(\mathrm{H})$, epididymal (ED) and dorsolumbal (DL) adipose tissues were taken from each animal in doublets after decapitation, immediately frozen in liquid nitrogen and stored in $-80^{\circ} \mathrm{C}$ until use. The protocol of the study was approved by the Central Commission for Animal Welfare of the Czech Republic.

Serum total cholesterol (TC) and triglycerides (TG) and non-esterified fatty acids (NEFA) were measured on an automatic analyzer (COBAS MIRA+, Roche, Switzerland) by commercially available enzymatic assay kits from Roche Diagnostics and Wako, Japan (NEFA). Lipoprotein fractions (VLDL at $\mathrm{d}<1.006$ $\mathrm{g} / \mathrm{ml}, \mathrm{LDL}$ at $\mathrm{d}=1.006-1.063 \mathrm{~g} / \mathrm{ml}$ and HDL at $\mathrm{d}=$ $1.063-1.210 \mathrm{~g} / \mathrm{ml}$ ) were isolated from pooled serum of each group by sequential ultracentrifugation (Havel et al. 1955).

Tissues for RNA isolation were homogenized and total RNA isolated by NucleoSpin ${ }^{\circledR}$ RNA II kits (Macherey-Nagel, Germany). The isolated RNA (100 ng) was transcribed into cDNA using RevertAid ${ }^{\mathrm{TM}}$ First Strand cDNA Synthesis Kit (Fermentas Life Sciences) in a total volume of $20 \mu \mathrm{l}$. One microliter of cDNA was used for the subsequent real-time polymerase chain reaction (qPCR) run on the Rotor-Gene RG 3000 (Corbett Research, Australia) using the Rotor-Gene 6.0.16 software version. PCR amplifications were performed in a total volume of $25 \mu 1$, containing $1 \mu \mathrm{l}$ cDNA sample, $3 \mu 125 \mathrm{mM} \mathrm{MgCl}_{2}, 2.5 \mu 1$ Taq Buffer, $1 \mu 1$ DMSO (Sigma), $0.5 \mu 12 \mathrm{mM}$ dNTP mix, $1 \mu 1$ 10x concentrate in DMSO SYBER Green I (Rockland, ME, USA), $0.2 \mu 150 \mu \mathrm{M}$ both forward and reverse primer and $0.1 \mu 15 \mathrm{u} / \mu 1 \mathrm{Taq}$ DNA Polymerase (Fermentas). Each PCR amplification was performed in triplets, using the following conditions: $5 \mathrm{~min} 95{ }^{\circ} \mathrm{C}, 35$ repeats of $20 \mathrm{~s}$ $95^{\circ} \mathrm{C}, 20 \mathrm{~s} 67{ }^{\circ} \mathrm{C}(L P L)$ or $46^{\circ} \mathrm{C}($ APOA1) and $20 \mathrm{~s}$ $72{ }^{\circ} \mathrm{C}$, and $10 \mathrm{~min} 72{ }^{\circ} \mathrm{C}$. Mouse cyclophilin B gene $(\mathrm{CPH})$ was used as inner standard (housekeeping gene) in both kinds of reactions. The following primer sets were used: $L P L$, sense 5'-AGC CCC CAG TCG CCT TTC TCC T-3' and antisense 5'-TGC TTT GCT GGG GTT TTC TTC ATT CA-3'; APOA1, sense 5'-CGT GGC TCT GGT CTT CCT GAC-3' and antisense 5'-CAC CCA ATC TGT TTC TTT CTC C-3', and $C P H$, sense 5'-ACT ACG GGC CTG GCT GGG TGA G-3' and antisense 5'-TGC CGG AGT CGA CAA TGA TGA-3'. All primers were obtained from Generi Biotech, Czech Republic. Following PCR, melting analysis was performed. To measure the gene expression quantitatively, the external standards for each target gene ( $L P L$ and APOA1) as well as for $C P H$ were constructed by cloning purified PCR products into pDrive Cloning Vector (QIAGEN ${ }^{\circledR}$ PCR Cloning ${ }^{\text {PLUS }}$ Kit). Ligated fragments were transformed into QIAGEN EZ Competent Cells (Qiagen). Plasmid DNA was isolated by fast alkaline lysis, its concentration detected (UV 1101, Biotech Photometer) and the concentration of $L P L, A P O A 1$ and $C P H$ calculated. Then, serial dilutions were prepared and run in $\mathrm{qPCR}$ as standard curves. Target gene: housekeeping gene ratios were compared. Results for total cholesterol, triglycerides and non-esterified fatty acids were analyzed by analysis of variance (ANOVA). When significantly different by ANOVA, the Student-Newman-Keuls (SNK) test was used (Glantz 1992). The expression of LPL and APOA1 were compared using Kruskal-Wallis test followed by Dunn's test if needed (Glantz 1992).

During 4-week ethanol and diet treatment, there were no significant differences in diet consumption. However, the weight of mice fed the HF diet and $\mathrm{EtOH}$ (group IV) increased more throughout the experiment than that of mice fed the ST diet $(2.80 \pm 1.69,3.11 \pm 1.01$, $4.20 \pm 1.48$, and $5.80 \pm 1.48 \mathrm{~g}$, group I to group IV). Mice 
Table 1. Concentration of plasma lipids and lipoproteins.

\begin{tabular}{|c|c|c|c|c|c|}
\hline & $\begin{array}{c}\text { ST, W } \\
\text { (Group I) }\end{array}$ & $\begin{array}{l}\text { ST, EtOH } \\
\text { (Group II) }\end{array}$ & $\begin{array}{c}\text { HF, W } \\
\text { (Group III) }\end{array}$ & $\begin{array}{c}\text { HF, EtOH } \\
\text { (Group IV) }\end{array}$ & $\mathbf{p}$ \\
\hline \multicolumn{6}{|c|}{ Lipids (mmol/l) } \\
\hline$T C$ & $1.67 \pm 0.20$ & $1.65 \pm 0.26$ & $2.25 \pm 0.41{ }^{*}, \#$ & $2.10 \pm 0.29{ }^{*}, \#$ & $<0.001$ \\
\hline$T G$ & $0.59 \pm 0.14$ & $0.50 \pm 0.10$ & $0.55 \pm 0.10$ & $0.47 \pm 0.06$ & ns \\
\hline$N E F A$ & $0.82 \pm 0.15$ & $0.76 \pm 0.15$ & $0.86 \pm 0.20$ & $0.93 \pm 0.14$ & $\mathrm{~ns}$ \\
\hline \multicolumn{6}{|c|}{ Lipoproteins (mmol/l) } \\
\hline$V L D L-T G$ & 0.31 & 0.27 & 0.33 & 0.25 & - \\
\hline$L D L-C$ & 0.27 & 0.23 & 0.36 & 0.29 & - \\
\hline$H D L-C$ & 1.40 & 1.40 & 1.36 & 1.50 & - \\
\hline
\end{tabular}

Data for lipids are mean \pm S.D. The differences in total cholesterol (TC), triglycerides (TG) and non-esterified fatty acids (NEFA) were evaluated by ANOVA and SNK tests. Significantly different from: * group I, \# group II. Data for VLDL-triglycerides, LDL- and HDLcholesterol (LDL-C and HDL-C, respectively) were obtained after ultracentrifugation of pooled serum samples. EtOH - ethanol, HF - high-fat diet, ST - standard laboratory diet, W - water.

Table 2. Expression of $L P L$ in heart, epididymal and dorsolumbal adipose tissue and expression of $A P O A 1$ in the liver.

\begin{tabular}{|c|c|c|c|c|c|}
\hline & $\begin{array}{c}\text { ST, W } \\
\text { (Group I) }\end{array}$ & $\begin{array}{l}\text { ST, EtOH } \\
\text { (Group II) }\end{array}$ & $\begin{array}{c}\text { HF, W } \\
\text { (Group III) }\end{array}$ & $\begin{array}{c}\text { HF, EtOH } \\
\text { (Group IV) }\end{array}$ & $\mathbf{p}$ \\
\hline \multicolumn{6}{|c|}{ LPL:CPH ratio } \\
\hline$L P L-H$ & $22.3(18.8 ; 39.3)$ & $13.1(11.0 ; 21.8)$ & $44.0(29.2 ; 58.0)$ & $175.9(74.8 ; 232.0)^{\#}$ & $<0.001$ \\
\hline$L P L-E D$ & $149.9(100.7 ; 215.5)$ & $94.8(43.0 ; 118.7)$ & $55.6(51.0 ; 167.6)$ & $1163.0(197.3 ; 1794.7)^{\#-1}$ & $<0.05$ \\
\hline$L P L-D L$ & $3.4(0.6 ; 13.3)$ & $4.3(0.4 ; 11.4)$ & $0.3(0.3 ; 7.8)$ & $9.2(1.0 ; 13.1)$ & ns \\
\hline \multicolumn{6}{|c|}{ APOA1:CPH ratio } \\
\hline $\begin{array}{l}A P O A-I \\
\left(x 10^{3}\right)\end{array}$ & $327.0(217.3 ; 658.4)$ & $625.2(137.0 ; 713.0)$ & $\begin{array}{c}533.0(107.5 \\
700.0)\end{array}$ & $297.0(130.7 ; 338.3)$ & $\mathrm{ns}$ \\
\hline
\end{tabular}

Data are median (1st quartile; 3rd quartile). The differences in $L P L$ expression in heart ( $L P L-H)$, epididymal $(L P L-E D)$ and dorsolumbal $(L P L-D L)$ adipose tissues were evaluated by Kruskal-Wallis statistics and if needed by Dunn's test. Significantly different from: ${ }^{\#}$ group II, ${ }^{+}$group III. EtOH - ethanol, HF - high-fat diet, ST - standard chow, W - water.

fed the HF diet with EtOH (group IV) had significantly lower liquid consumption than all other groups $(5.94 \pm 0.69, \quad 5.81 \pm 1.38, \quad 6.01 \pm 0.34$ and $4.90 \pm 1.12$ $\mathrm{ml}$ /day/animal). There was no difference in total cholesterol concentration between groups of animals fed the same diet, but concentrations of total cholesterol in both groups fed the HF diet were higher than in groups on ST diet $(\mathrm{p}<0.001)$ (Table 1). There were no differences in TG and NEFA concentrations between the groups. The data for triglycerides and cholesterol concentrations in VLDL, LDL and HDL (Table 1) did not show any pronounced differences; however, due to use of pooled serum samples, the data cannot be evaluated with respect to statistical significance. The effect of ethanol consumption together with HF diet on the $L P L$ expression was studied in the heart $(L P L-H)$, epididymal ( $L P L-E D)$ and dorsolumbal ( $L P L-D L)$ adipose tissue, and on the APOA1 expression in the liver (Table 2). The $L P L-H$ expression was significantly higher in mice fed the HF diet and EtOH than in mice fed the ST diet and EtOH $(\mathrm{p}<0.001)$. The LPL-ED expression was significantly higher in mice fed the HF diet and EtOH than in mice fed ST diet with EtOH and than in mice fed HF diet with water $(\mathrm{p}<0.05)$. There was no effect of alcohol and HF diet on the $L P L-D L$ expression and on the APOA1 expression in the liver.

We demonstrated that $L P L$ expression is upregulated in the heart and epididymal fat (but not in 
dorsolumbal fat) of C57BL/6 mice given $5 \%$ ethanol and high-fat diet. No effect of ethanol consumption can be observed when the mice are fed only the standard laboratory diet. The APOA1 expression was not affected either by ethanol consumption or HF diet. Our findings are in rather good agreement with observations in humans that LPL activity is increased after a period of moderate alcohol consumption (Schneider et al. 1985, Nishiwaki et al. 1994, Kovář and Poledne 2004). It can be speculated that such an increase in $L P L$ expression represents a metabolic response to the higher supply of TRL to tissues due to an increased dietary fat intake and increased VLDL production from the liver because of the lipogenic effect of ethanol (Sane et al. 1984, Baraona and Lieber 1998). Increased LPL activity should then attenuate the response of triglyceridemia to alcohol intake and may explain why there are no differences in TG concentration between groups. At the moment we have no data available to suggest the mechanism of LPL upregulation - it can be speculated that activation of gene expression through PPAR-alpha due to increased fatty acid supply may be involved (Jump et al. 2005). However, our findings of upregulation of $L P L$ expression by alcohol consumption need to be confirmed in independent experiments. Rather surprisingly, we did not observe any effect of ethanol on cholesterol and HDL-C concentration in the serum. Increased level of HDL-C is considered to be the main part of ethanol-mediated cardiovascularprotective effect in humans (Gaziano et al. 1993, Chung et al. 2003, Hansen et al. 2005, Naissides et al. 2006). On the contrary, in mice, alcohol consumption was found to be associated with both an increase (Bentzon et al. 2001) and a decrease in HDL-C level (Emeson et al. 1995, 2000, Munday et al. 1999, Escola-Gil et al. 2004). In the light of these facts, we can speculate that in our study, in which no cholesterol was added to the HF-diet, the impact on HDL-C could be minimalized. It was shown that apo A-I synthesis and secretion from hepatocytes is increased when HepG2 cells are incubated with ethanol (Amarasuriya et al. 1992, Dashti et al. 1996). Our data do not support such findings; however, there could be interspecies differences in regulation of apo A-I synthesis as can also be seen from inconsistent effects of alcohol consumption on HDL-C concentration in mice.

In conclusion, our results demonstrate that moderate ethanol consumption (together with an increased intake of fat) results in upregulation of $L P L$ expression in a tissue-specific manner in C57BL/6 mice.

\section{Acknowledgements}

This work was supported by grant \# NR/7847-3 from IGA MH CR.

\section{References}

AMARASURIYA RN, GUPTA AK, CIVEN M, HORNG YC, MAEDA T, KASHYAP ML: Ethanol stimulates apolipoprotein A-I secretion by human hepatocytes: implications for a mechanism for atherosclerosis protection. Metabolism 41: 827-832, 1992.

BARAONA E, LIEBER CS: Alcohol and lipids. Recent Dev Alcohol 14: 97-134, 1998.

BENTZON JF, SKOVENBORG E, HANSEN C, MOLLER J, DE GAULEJAC NS, PROCH J, FALK E: Red wine does not reduce mature atherosclerosis in apolipoprotein E-deficient mice. Circulation 103: 1681-1687, 2001.

CHUNG BH, DORAN S, LIANG P, OSTERLUND L, CHO BH, OSTER RA, DARNELL B, FRANKLIN F: Alcoholmediated enhancement of postprandial lipemia: a contributing factor to an increase in plasma HDL and a decrease in risk of cardiovascular disease. Am J Clin Nutr 78: 391-399, 2003.

CORDOVA AC, JACKSON LS, BERKE-SCHLESSEL DW, SUMPIO BE: The cardiovascular protective effect of red wine. J Am Coll Surg 200: 428-439, 2005.

CRIQUI MH, COWAN LD, TYROLER HA, BANGDIWALA S, HEISS G, WALLACE RB, COHN R: Lipoproteins as mediators for the effects of alcohol consumption and cigarette smoking on cardiovascular mortality: results form the Lipid Research Clinics Follow-up Study. Am J Epidemiol 126: 629-637, 1987.

DASHTI N, FRANKLIN FA, ABRAHAMSON DR: Effect of ethanol on the synthesis and secretion of apoA-I- and apoB-containing lipoproteins in HepG2 cells. J Lipid Res 37: 810-824, 1996.

EMESON EE, MANAVES V, SINGER T, TABESH M: Chronic alcohol feeding inhibits atherogenesis in C57BL/6 hyperlipidemic mice. Am J Pathol 147: 1749-1758, 1995. 
EMESON EE, MANAVES V, EMESON BS, CHEN L, JOVANOVIC I: Alcohol inhibits the progression as well as the initiation of atherosclerotic lesions in C57Bl/6 hyperlipidemic mice. Alcohol Clin Exp Res 24: 1456-1466, 2000.

ESCOLA-GIL JC, CALPE-BERDIEL L, RIBAS V, BLANCO-VACA F: Moderate beer consumption does not change early or mature atherosclerosis in mice. Nutr J 3: 1, 2004.

GAZIANO JM, BURING JE, BRESLOW JL, GOLDHABER SZ, ROSNER B, VANDENBURGH M, WILLETT W, HENNEKENS CH: Moderate alcohol intake, increased levels of high-density lipoprotein and its subfractions, and decreased risk of myocardial infarction. N Engl J Med 329: 1829-1834, 1993.

GLANTZ SA: Primer of Biostatistics. Third edition. McGraw-Hill, Inc, New York, 1992.

HANSEN AS, MARCKMANN P, DRAGSTED LO, FINNE NIELSEN IL, NIELSEN SE, GRONBAEK M: Effect of red wine and red grape extract on blood lipids, haemostatic factors, and other risk factors for cardiovascular disease. Eur J Clin Nutr 59: 449-455, 2005.

HAVEL RJ, EDER HA, BRAGDON JH: The distribution and chemical composition of ultracentrifugally separated lipoproteins in human serum. J Clin Invest 34: 1345-1353, 1955.

JUMP DB, BOTOLIN D, WANG Y, XU J, CHRISTIAN B, DEMEURE O: Fatty acid regulation of hepatic gene transcription. J Nutr 135: 2503-2506, 2005.

KOVÁŘ J, POLEDNE R: Influence of moderate alcohol consumption on lipoprotein metabolism (in Czech). Cor Vasa 46: 110-114, 2004.

LANGER RD, CRIQUI MH, REED DM: Lipoproteins and blood pressure as biological pathways for effect of moderate alcohol consumption on coronary heart disease. Circulation 85: 910-915, 1992.

MUNDAY JS, THOMPSON KG, JAMES KA, MANKTELOW BW: The effect of moderate alcohol consumption as either red or white wine in the C57BL/6 mouse atherosclerosis model. Coron Artery Dis 10: 97-102, 1999.

NAISSIDES M, MAMO JC, JAMES AP, PAL S: The effect of chronic consumption of red wine on cardiovascular disease risk factors in postmenopausal women. Atherosclerosis 185: 438-445, 2006.

NISHIWAKI M, ISHIKAWA T, ITO T, SHIGE H, TOMIYASU K, NAKAJIMA K, KONDO K, HASHIMOTO H, SAITOH K, MANABE M, et al.: Effects of alcohol on lipoprotein lipase, hepatic lipase, cholesteryl ester transfer protein, and lecithin:cholesterol acyltransferase in high-density lipoprotein cholesterol elevation. Atherosclerosis 111: 99-109, 1994.

RIMM EB, KLATSKY A, GROBBEE D, STAMPFER MJ: Review of moderate alcohol consumption and reduced risk of coronary heart disease: is the effect due to beer, wine, or spirits. BMJ 312: 731-736, 1996.

SANE T, NIKKILA EA, TASKINEN MR, VALIMAKI M, YLIKAHRI R: Accelerated turnover of very low density lipoprotein triglycerides in chronic alcohol users. A possible mechanism for the up-regulation of high density lipoprotein by ethanol. Atherosclerosis 53: 185-193, 1984.

SCHNEIDER J, LIESENFELD A, MORDASINI R, SCHUBOTZ R, ZOFEL P, KUBEL F, VANDRE-PLOZZITZKA C, KAFFARNIK H: Lipoprotein fractions, lipoprotein lipase and hepatic triglyceride lipase during short-term and long-term uptake of ethanol in healthy subjects. Atherosclerosis 57: 281-291, 1985.

SUH I, SHATEN BJ, CUTLER JA, KULLER LH: Alcohol use and mortality from coronary heart disease: the role of high-density lipoprotein cholesterol. The Multiple Risk Factor Intervention Trial Research Group. Ann Intern Med 116: 881-887, 1992.

\section{Corresponding author}

Jan Kováŕ, Institute for Clinical and Experimental Medicine, Laboratory for Atherosclerosis Research, Vídeňská 1958/9 14021 Prague 4, Czech Republic. E-mail: jan.kovar@medicon.cz 